\title{
THE CONTRASTING EFFECTS OF BOARD COMPOSITION AND STRUCTURE ON IPO FIRM UNDERPRICING IN A DEVELOPING CONTEXT
}

\section{Introduction}

A dominant feature in agency theory associated with the mitigation of asymmetric information costs between principals (owners and investors) and agents (incumbent management) is the role ascribed to the board of directors in aligning interests of these two groups. Board structure and composition is a key feature in ensuring the mitigation of these costs through optimal monitoring and surveillance of management and the alignment of interests with those of shareholders (Filatotchev and Bishop, 2002). However while this shareholder agency model has come to dominate governance best practice and legislation in UK and US markets, thereby commonly termed as Anglo-American, a rival stakeholder model, viewing the firm as a social entity responsible and accountable to a wide variety stakeholders encompassing suppliers, owners, customers, employees, management, government and local communities, is more prevalent in non-Anglophone markets and termed as European (West, 2006). However both models have an incongruous fit when adopted and applied in societies with very different social values and norms, such as those commonly found across Sub Saharan Africa (SSA) where prescriptions are largely at odds with the communitarian nature of indigenous culture (West (2006); Platteau (2007); Englebert (2000)). As a consequence we are motivated to focus our study on SSA region which is characterised by indigenous societies with often alien cultures, values and social norms to those engendered by neoclassical markets-orientated institutions and the AngloAmerican model of governance.

An initial public offering (IPO) represents the first major liquidity event in a firm's lifecycle with insiders realizing value from the sale of their equity stakes and consequent 
diversification of ownership (Filatotchev and Bishop, 2002). It also provides a window through which the neoclassical institutions of the market can value the firm thus facilitating insiders to realize potential value through an opportunity to initiate investment exit strategies for the first major time during the firm's life cycle (Bruton et al, 2009). Underpricing of newly issued stock at IPO is a critical measure of the value the market attributes to the firm and is representative of the value attributed to board level characteristics that mitigate asymmetric information and align the interests of principals and agents. However governance across developing regions such as SSA is commonly shaped by the interplay between formal institutions such as legal codification and legislation, adoption of international best practice recommendations and much deeper and pervasive informal institutions enshrined in the values and behavioural norms of the indigenous society itself (Williamson (2000); North (1991)). The successful adoption of transplanted legal and governmental institutions inherited from former colonial metropoles is hinged on the cultural compatibility of these institutions with the deeper informal institutions of the indigenous societies. This is particularly evident in the very different economic performance of countries across the SSA region ranging from the successful adoption and cultural compatibility of English common law and neoclassical institutions in Botswana (Hjort, 2010) to the lack of reception and incompatibility of inherited institutions across much of the rest of SSA (Joireman (2005); Englebert (2000); Platteau (2007)). However a major feature in terms of the adoption and in particular enforcement of formal institutions is the lack of an effective and commercially trained judiciary and an incomplete body of case law and legal bureaucracy in the case of civil code countries (Joireman, 2005) together with often undercapitalized regulatory enforcement agencies (Quintyn and Taylor, 2005). However the greatest challenge to the successful adoption of the Anglo-American or European stakeholder model of governance is from the indigenous society cultural and social values and norms 
engendered by the South African term "ubuntu". This ubuntu concept of development signifies a commitment to coexistence, consensus and consultation where indigenous elders rule by consultation with all stakeholders rather than by direct authoritative means (Rossouw (2005); West (2006)). This value system undermines the values and goals envisaged by the Anglo-American model as it renders the exclusive focus on shareholder's interests impossible owing to the necessity of equal consideration of values such as coexistence, concesus and consultation that are central tenets of ubuntu philosophy (West (2006); Rossouw (2005)). The combination of ubuntu philosophy and African values together with often very strong ethnic allegiances which themselves are enshrined in informal institutions ranging from language to cultural and societal beliefs and behavioural norms in addition to alienation from inherited colonial era institutions engendering economic and social outcomes at odds with those of the underlying societies (Englebert (2000); Joireman (2005)) creates significant challenges in terms of best practice governance in terms of optimal board structure and independent monitoring mechanisms (Jensen and Meckling (1976); Fama and Jensen (1983); Kalbers and Fogarty (1998)).

This paper examines IPO underpricing in a comprehensive sample of IPO firms from across the Sub Saharan African (SSA) region excluding South Africa. This region is particularly interesting as political economies and formal economic activity are dominated by social elites (Lavelle (2001); Hearn and Piesse (2009)) while there exist sharp differences between governmental and legal institutions in French and Portuguese civil code as opposed to English common law countries (La Porta et al (2008); Joireman (2001)). The former being characterised by markets such as BRVM (Cote d'Ivoire) ${ }^{1}$, Cameroon, Cape Verde Islands and Mozambique and the latter by Ghana, Nigeria, Kenya, Uganda, Zambia, Botswana and

\footnotetext{
${ }^{1}$ The Francophone West African Economic and Monetary Union (also known Union Monétaire et Économique de l'Afrique de l'Ouest (UMEAO)) countries include Cote d'Ivoire, Benin, Togo, Burkina Faso, Mali, Niger, Senegal and Guinea-Bissau
} 
Namibia (La Porta et al, 2008)). SSA markets have also benefitted from active encouragement by local governments influenced by market-orientated policies of the international financial institutions and structural reform packages (Hearn and Piesse, 2009) geared towards the attraction of foreign investment capital. Equally many markets have adopted and revised regulatory and governance legislation in line with international best practice and following that of the UK Cadbury Report, US Sarbanes-Oxley, South Africa's King I and II reports and OECD guidance principles. As such we combine agency and IPO signalling perspectives to study the impact on IPO underpricing arising from the adoption of various board-level governance mechanisms as well as from board diversity with directors being either from foreign or more specifically OECD countries or being high profile figures in the indigenous local society. Signalling research suggests that underpricing can be reduced by idiosyncratic signals through which IPO issuance investment banks convey information about the firm's quality to outside external investors (Sanders and Boivie, 2004). In contrast the agency-based viewpoint looks on these signals as being associated with the firm's intrinsic ownership structure and governance roles of boards envisaged as part of their structure and composition (Filatotchev and Bishop, 2002).

This paper extends the study of IPOs in three major ways. The first studies the differences in the signalling effects from the adoption of governance measures (establishment of nominally independent committees, board size and board independence). The second contribution is in the study of the signalling effects arising from the composition of the board with consideration of directors from foreign, and specifically OECD governance jurisdictions, as well as high profile society positions in indigenous local society. The third contribution is associated with the study being undertaken in one of the poorest world regions and in one dominated by indigenous societies that have had to adopt often alien formal institutions from former colonial metropoles. Furthermore many countries in this region are characterised by 
narrow formal economies dominated by either agricultural or extractive industries and exhibit sharp differences between civil code law and common law institutions inherited from former Portuguese, French and British colonial metropoles. These differences are particularly important in determining firm capital structure (La Porta et al $(2002,2008)$ ) as well as in the protection of property rights over a financial security's entitlements to corporate cash flows (La Porta et al, 2008) and private benefits of control (Boulton et al, 2009). Extending the study across a wider range of institutional environments facilitates the extension of the study of agency and signalling theory in application outside the study of the United States and UK which are common in the literature (Bruton et al, 2009).

Agency-based perspectives on the roles of board-level governance measures generally propose the separation and independence of roles, committees, monitoring and surveillance bodies. There is a considerable literature regarding the reduction of asymmetric information from the necessity of independence in oversight and monitoring of board activities a higher number of truly independent non-executive directors is likely to reduce asymmetric information. As such we conjecture that board independence ratio is negatively related to underpricing. There is a larger literature concerning the role of nominally independent board committees in their ability to provide effective monitoring and oversight. Downes and Heinkel (1982) question the additional benefit of committees over and above the role of independent directors in the oversight of board level decision making. Furthermore Anderson and Reeb (2004) and Golden and Zajac (2001) question the true level of independence and impartiality of committees from the influence of CEO and executive directors while Filatotchev and Bishop (2002) find evidence that both non-executive directors and committees are largely selected by incumbent executive board members. Turley et al (2004) find that the formation and reliance of firms on independent audit committees actually cause net increases in agency and monitoring costs. However owing to 
a lack of consensus in the literature we conjecture that the establishment of board committees will reduce informational asymmetry and underpricing. Finally the board of directors itself can be viewed as a tool that is useful in mitigating asymmetric information with larger boards being more dispersed and incurring greater coordination costs than smaller counterparts where communication is engendered. As such we conjecture that increases in board size will be positively related to increases in underpricing reflecting this asymmetric information cost from poorer coordination. However the composition of the board itself is a vital tool in both mitigating asymmetric information and in signalling quality in terms of both the additional human capital foreign directors can bring with them as well as their overseas networks (Cohen et al, 2008). In the light of neoclassical market institutions the increased presence of foreign and in particular OECD origin directors would be perceived as maximising firm value and thus minimising potential misalignment of interests between investors and incumbent management. As such we conjecture that the presence of foreign and in particular OECD directors will reduce levels of underpricing. However quite the opposite is true with increasing numbers of high profile figures from indigenous society as these are more likely to be closely linked to alien local society interests and thus at odds with external market investors. As such we conjecture that the presence of high society directors will increase levels of underpricing in line with increases in agency costs through potential for misalignment of interests and greater asymmetric information.

This paper is structured as follows: The next section outlines hypothesis construction and details the model used while section 3 introduces the data and outlines SSA regional markets. Section 4 provides the empirical results while the final section concludes.

\section{Hypotheses and Model}


This study is focussed on the performance effects of IPO firms from a variety of corporate governance mechanisms, namely establishment of independent committees, board size and proportion of board independence, or otherwise known as level of non-executive independent directors to incumbent executive directors. In addition the contrasting effects of foreign, and in particular OECD, and indigenous high society directors are studied in the context of additional networks to enhance firm value but within the unique context of conflicting informal and formal institutions between indigenous society and governance legislation.

\subsection{Dependent variables}

\subsection{Underpricing}

Initial returns are used as a measure of underpricing. This is calculated over a period of 2 (and 4 weeks) following listing on exchange. This is due to concerns over the severity of illiquidity in Sub Saharan Africa's equity markets causing price-rigidity (Smith and Jefferis (2005); Hearn and Piesse (2010)) that in turn would inhibit the movement of prices in relation to their ability to reflect order flow and information (O'Hara, 2003). In line with Filatotchev and Bishop (2002) underpricing is calculated as the difference between stock price at 2 (and 4 weeks) and the issue price divided by the issue price:

$$
I R_{i}=\mathbf{T} l o \sin g_{i}-I_{s s u e_{i}} \not I_{s s u e}
$$

\subsection{Board structure and composition effects on IPO firm performance}

The mainstream international corporate governance literature views an IPO as being the first major "liquidity event" in the life cycle of fast growing firms when founders and initial investors (corporate insiders) begin the process of realizing the value of their ownership stake in the firm (Brav and Gompers, 2003). However the IPO process introduces a number of potential agency conflicts for the various principal and agent parties involved (Bruton et al, 
2009). Adverse selection and moral hazard problems arise from the asymmetric information between new owners (investors) and incumbent managers (agents) as there are incentives for the latter to mislead or even worse expropriate the former (Bruton et al (2009); Boulton et al (2009)). As such the board of directors itself can be viewed as being a tool which can act to better align incentives of various principals and agents and facilitate communication and information disclosure thereby reducing asymmetric information (Jensen and Meckling, 1976). The literature regarding the beneficial impact arising from firms establishing independent board level committees to oversee effective information disclosure, executive remuneration and monitoring is more diffuse in its findings. Daily (1995) and Dalton et al (1998) detail how the majority of corporate decision-making is not undertaken through the committees but rather by the board itself while Shivdasani and Yermack (1999) question the independence of committees from CEO control. However given that the establishment of committees with at least nominal independence is a costly process for firms and is recommended in best practice governance guidelines in OECD and Cadbury Report I conjecture that the signalling of quality role of committee establishment will reduce underpricing and costs of equity while being associated with better capitalized, larger value firms that are able to implement these costly procedures. Consequently we test the following hypotheses:

H1. Establishment of committee(s) is negatively associated with IPO-firm underpricing The literature regarding the impact of board size on firm performance is largely derived from Jensen (1993) where smaller boards were argued to be the result of technological and organizational change that facilitates reduction of costs and corporate downsizing. Hermalin and Weisbach (2003) found evidence suggesting that smaller boards are more effective than 
large boards as agency costs increase owing to a greater number of board members adopting the role of free-riders. Jensen (1993) found further evidence for the lack of cohesiveness in large boards leading to a lack of coordination and communication that reduced the effectiveness of the board as a monitoring tool in the reduction of agency costs. As such I conjecture that larger boards to be in larger firms with higher value and incurring higher levels of underpricing and cost of equity. Consequently we test the following hypotheses:

H2. Board size is positively associated with IPO-firm underpricing

The literature regarding the impact of board independence commonly focuses on the monitoring role engendered by non-executive directors over incumbent executives which in turn mitigates informational asymmetry and reduces underpricing (Chahine and Goergen, 2009). Chahine and Goergen (2009) find empirical evidence that higher levels of board independence leads to lower levels of underpricing. Consequently we test the following hypotheses:

H3. Board independence is negatively associated with IPO-firm underpricing

More recent research suggests that the connectivity and networks of individual directors who make up the composition of the board effect the value of the firm (see Certo et al, 2001). Higgins and Gulati (1999) reveal evidence that the greater the collective number of outside links associated with the members of the board the stronger the signal of the firms quality and greater alignment of interests between outside investors and management (Cohen et al, 2008). This would be particularly true given the often alien relationship between African traditional social values, envisaged under ubuntu philosophy (West (2006); Rossouw (2005)) 
and those engendered in Anglo-American models of corporate governance. Consequently we test the following hypotheses:

H4. The number of Foreign directors is negatively associated with IPO-firm underpricing

H5. The number of OECD directors is negatively associated with IPO-firm underpricing

Contrastingly an increasing number of prominent high society figures from the local indigenous society would indicate an increased likelihood of misaligned interests between the powerful social elites and their traditional African values represented by ubuntu and those engendered by Anglo-American corporate governance practice. As such given that these would be at odds with each other (West (2006); Rossouw (2005)) there is a greater probability of asymmetric information. Consequently we test the following hypothesis:

H6. The number of indigenous high society directors is positively associated with IPO-firm underpricing

OLS regressions were used to test these hypotheses using unbalanced panels. This takes the form:

Performance $_{i}=$ Cons $\tan t+\beta_{\text {Governance }}$ Governance $+\beta_{\text {Legal }}$ Legal Controls $_{i}$ $+\beta_{\text {Firm }}$ Firm Controls $_{i}+\beta_{\text {IPO }}$ IPO Controls C $_{i}+\varepsilon_{i}$

where performance is dependent variable relating to underpricing at 2 and 4 weeks respectively as defined in preceding section. Committee is a dummy variable taking value 1 if condition is satisfied and 0 otherwise. Log Board size is the natural logarithm of the total 
number of both executive and non-executive directors and is taken to include those designated as "executive directors" in civil code markets where boards are unitary in structure and supervisory in function. Board independence ratio is proportion of nonexecutive directors to executive counterparts. The number of foreign directors is the total number of foreign directors on the board while the number of OECD directors are those foreign directors of OECD origin. The number of high society directors are those directors who occupy prestigious military, academic, governmental positions in the indigenous society within the domestic country.

A basic materials and construction industry dummy is included to account for the high state involvement in extractive industries. This takes the value 1 if the firm's activities fall within the industry classifications of this dummy and 0 otherwise. Legal origin is a dummy taking the value 1 for civil code law markets and 0 for common law. The inclusion of this dummy precludes taking country fixed effects in the unbalanced panel regressions as the dummy itself accounts for long term time invariant structural rigidities engendered by the transplanted legal system. Countries are categorised as civil or common law using La Porta et al (2008). Firm-level controls used in each case include natural logarithm of US\$ converted revenues in IPO year (Filatotchev and Bishop (2002); Filatotchev et al (2005)) given the wide dispersion of sample group firms unndergoing IPOs ranging from the privatizations of very large former state owned enterprises to smaller high growth technology companies with considerable variation in revenues and firm age, defined as difference in years between year of establishment and IPO. The natural logarithm of age, defined as difference between year of firm establishment and IPO year, was also used. IPO controls are centred on the natural logarithm of the ratio between shares offered and total number of shares issued and outstanding. 


\section{Method}

\subsection{Sample}

Comprehensive lists of IPO's and listings were obtained direct from the national exchanges of Cape Verde Islands (Bolsa de Valores de Cabo Verde), Cameroon (Bourse de Douala), BRVM (Cote d'Ivoire), Malawi, Kenya, Uganda, Tanzania, Zambia, Namibia, Botswana, Mozambique, Mauritius and Ghana for the period 2000 to 2009. Nigerian lists were only available from 2002 to 2009 . These were cross checked with national stock exchange websites and from similar lists obtained from major brokerage houses to ensure accuracy in the case of Nigeria. This resulted in a list of 172 listings having taken place across the region during the period 2000 to 2009.

Flotation prospectuses were then hand-collected from the Ghana and Tanzania (Dar Stock Exchange) stock exchanges and Bolsa de Valores de Cabo Verde (Cape Verde Islands exchange) as well as from the stock exchange website for the Bourse de Douala (Cameroon exchange) (DSX website, 2010) while the Thomson Corporation Perfect Information database was used in the first instance to source Nigerian, Malawian and Kenyan prospectuses. This was further augmented by sourcing individual prospectuses from the national stock exchanges and individual firms although response rates were low in sourcing prospectuses direct from firms themselves. Pangea Stockbrokers (Zambia) as well as individual floated firms were the source of prospectuses for the Zambian stock market. This resulted in the successful collection of 104 prospectuses from the original list of 172 .

I then exclude readmissions and transfers of listings between main and development boards while also excluding demergers, reorganizations and flotation of preferred stock, convertibles, unit and investment trusts. Consequently the list of valid IPO prospectuses was reduced to the current sample size of 62 IPO firms. These floated ordinary shares with single class voting rights. Share prices were obtained from Bloomberg, DataStream and direct from 
the national stock exchange in Cape Verde and Cameroon. US\$ Exchanges rates were obtained from Bloomberg. The classification of each market according to its legal origin was made using La Porta et al (2008).

\subsection{Sub Saharan African securities markets}

There are considerable differences between Sub Saharan Africa's stock markets with the greatest of these being between markets adhering to common as opposed to civil code commercial and regulatory law. However all markets are characterised by narrow political economies controlled by social and political elites (Lavelle (2001); Hearn and Piesse (2009)) and only a handful of brokerage firms and indigenous investment banks with minimal trading activity. The lack of an established domestic institutional investor community in many of the markets combined with poor infrastructure create further difficulties in attracting much needed foreign investment (Hearn and Piesse (2009)). An additional issue arises from trading activity occurring outside the formal exchanges with only the pre-agreed details being acknowledged during designated trading sessions as is the case in Ghana (Akotey, 2008).

The evidence in Table 1 detailing the sample structure reveals the more sporadic nature of listings across the region. Listings activity on the BRVM acting as the West African Francophone regional exchange is largely static during the sample period with notable exceptions being Onatel, the Burkina Faso telecommunications operator, two Bank of Africa affiliates from Niger and Benin, and a local Ivorienne firm. This regional focus to the listings on the otherwise inactive market (Lavelle, 2001) is largely the result of political pressure and a marketing drive designed to enhance the regional focus of the market (Hearn and Piesse, 2010). It is also facilitated in practice by the extended regional network of Société de Gestion et d'Intermediation (SGIs) in each member state of the Union Economique et Monétaire Ouest Africaine (UEMOA) who act as Chef de File (Lead 
Manager and underwriter) in flotations. The Cameroonian Bourse de Douala has been similarly inactive during its history since inception in 2003 and only attracted its first listings in 2008 (DSX website, 2010) while the Cape Verde Islands exchange has had greater success despite the very small size of the Islands economy in attracting four listings since its establishment in 2005 (BVC website, 2010). All three of the smaller illiquid civil code exchanges operate sophisticated electronic call auctions in order to achieve the greatest informational efficiency and have small brokerage communities dominated by the affiliate arms of major French, and Portuguese in case of Cape Verde, banks (Hearn and Piesse, 2010). There are substantially more IPOs in the case of the common law markets, namely Kenya, Nigeria, Zambia and Ghana, although the majority of these firms notably have head office locations in the immediate vicinity of the exchange itself providing further indication of the extremely narrow formal economy in each case. A greater proportion of IPOs in Zambia and Ghana than in Nigeria are made up from privatizations of government and state agency ownership stakes in former state owned enterprises (SOEs) while the listing of Gambia's Trust Bank on the Ghanaian exchange is a rare example of politically motivated listing between smaller common law West African markets.

\section{Table 1}

\section{Results}

\subsection{Descriptive statistics}

The evidence from Table 2 reveals considerable differences between civil and common law markets across Sub Saharan Africa in terms of levels of undepricing with the former having a mean discount of $5.5 \%$ in contrast to the latter of $39.10 \%$. Standard deviations in mean underpricing are also substantially larger across common law markets than in their civil code counterparts reflecting a greater dispersion of firms listing and raising external capital. This 
is in line with the findings of Levine (2005) and La Porta et al (2008) with evidence of a lack of a external market-based culture in civil law countries and consequently greater emphasis on bank-based and internal finance. This is further reflected in the mean listing size across civil code markets (US\$11.07m) which is eight times lower than that of common law markets (US\$80.66m). However there is also a considerable contrast in the size and development of markets across common law countries with the mean amounts raised being highest in Kenya and Nigeria with the latter being more than ten-times the mean value raised in its smaller common law neighbour of Ghana.

\section{Table 2}

The evidence from Table 3 reveals both low levels of correlation across variables within the sample and a general lack of statistical significance of the correlations that do exist. This would infer that multi-collinearity is not a significant concern for this sample in the ensuing regression models.

\section{Table 3}

\subsection{Impact of board governance attributes on IPO firm underpricing}

The evidence from Table 4 reveals that board size has a sizeable, positive and statistically significant relationship, albeit at a meagre $75 \%$ confidence level, with underpricing at both 2 and 4 weeks between models 1 and 2 . This is intuitively expected given the evidence in the extent literature regarding the negative impact of larger sized boards in terms of poorer coordination and inefficient communication and ability to exert control over incumbent management which acts to exacerbate agency costs and underpricing. This is also consistent with hypothesis 2 . The evidence from models 5 and 6 reveal that there is a very large, positive and highly statistically significant, at $95 \%$ confidence level, relationship between 
establishment of audit, finance and remuneration oversight and surveillance board committees and underpricing. This is not expected and is inconsistent from the propositions in hypothesis 1 , itself formed from the theoretical antecedents of shareholder, and specifically agency, theory. However this would be more consistent with the essentially neoclassical institutions of the market requiring price premiums, i.e. underpricing, owing to a lack of confidence in the establishment of such committees which are unlikely to be effective in the light of dominant informal institutions enforced by alien African, or ubuntu-type, values to those engendered by the Anglo-American model of governance. The evidence regarding board independence is inconclusive as while the relationship between this and underpricing if positive it is not statistically significant at any discernable level of confidence.

In general the evidence across all models in Table 4 regarding the relationships between control variables and underpricing reveals that there is a large, positive and statistically significant relationship between basic materials and construction industry dummy and IPO price premiums. This indicates that underpricing and agency costs are more prevalent in the extractive industries that are often state controlled in the narrow formal economies of SSA. Equally there is a similarly sized, statistically significant but negative relationship between underpricing and legal origin. This infers that underpricing is more prevalent in English common law countries than their civil code law counterparts which is intuitively expected from Levine (2005) and La Porta et al (2008) who cite external as opposed to internal financing of firms, and specifically market-orientated external financing is generally less developed in civil code law countries than their common law counterparts. Finally there is a large, positive and statistically significant relationship between underpricing and the natural logarithm of shares offered to total shares issued by IPO firms. This indicates that underpricing is typically sensitive to the size of share issues.

Table 5 


\subsection{The impact of board composition on underpricing}

The evidence from Table 5 reveals considerable differences in board composition and the resulting effect on underpricing. There are large, negative and statistically significant relationships between number of foreign and also number of OECD origin directors and underpricing, at both 2 and 4 weeks, although the former relationship is significant at a $75 \%$ confidence level while the latter is significant at a much higher $95 \%$ confidence margin. This would be intuitively expected and is consistent with hypotheses 4 and 5 owing to foreign directors bringing with them both expertise and established business networks to assist the growth and development of the firm. However it is also likely because foreign directors act to align the interests of both investors and incumbent management thereby mitigating agency costs and asymmetric information. In direct contrast there is a large, positive and statistically significant relationship between number of indigenous high society directors and underpricing although this is at a meagre $75 \%$ confidence margin. This would indicate that the neoclassical market institutions would put a price premium reflecting the likely higher asymmetric information and misalignment of interests between investors and incumbent management which would be especially prevalent given the predominance of informal institutions within which the IPO firms are embedded which have largely alien African values adhering to ubuntu-type philosophy (Rossouw (2005); West (2006)).

Generally the relationships between control variables and underpricing are in line with those reported in preceding section in respect of board structure and governance mechanisms. However there are some notable differences with legal origin dummy lacking statistical significance at any discernable confidence level in models 7 to 10 which relate foreign and OECD directors to underpricing. Equally the firm level control for natural 
logarithm of revenues is large, positive and statistically significant, albeit at a meagre $75 \%$ confidence level across all models 7 to 12 .

\section{Table 5}

\section{Conclusions}

This study investigates the structure and composition of IPO firm boards of directors and the resulting effects on underpricing determined by essentially neoclassical market institutions. This drew on a unique and comprehensive sample of sixty two IPO firms from across SSA equity markets is collected for the period 2000 to 2009 .

We have found considerable evidence that the internationally accepted AngloAmerican model of corporate governance focussing on shareholder value maximisation is inapplicable in regions such as SSA where it is at odds with the informal institutional society matrices of indigenous cultures and society. Consequently measures such as the establishment of independent board monitoring and surveillance committees actually act to increase underpricing and misalignment of interests between investor-owners and incumbent management. However in line with expectation larger boards are related to higher underpricing revealing the poorer coordinating and communication ability of larger bodies of directors. Most significantly we find that underpricing is actually reduced by increasing numbers of foreign and OECD-origin directors while being increased by increasing numbers of indigenous high society directors of local origin. This indicates that there are significant benefits in the attraction and retention of foreign directors in terms of their business networks and their alignment of interests between investor-owners and incumbent management. 


\section{References}

Akotey, A.J., 2007. Interview with Armah Akotey, Vice President of Investments, Databank Brokerage Ltd, Accra, Ghana. 23 December 2008.

Anderson, R., Mansi, S., Reeb, D., 2003. Founding family ownership and the agency costs of debt. Journal of Financial Economics, 68, 263-285

Boulton, T.J., Smart, S.B., Zutter, C.J., 2009. IPO underpricing and international corporate governance. Journal of International Business Studies, 19, 1-17

Brav, A., Gompers, P., 2003. The role of lock-ups in initial public offerings. The Review of Financial Studies, 16, 1-29

Bruton, G.D. Filatotchev, I., Chahine, S., Wright, M., 2009. Governance, Ownership Structure, and Performance of IPO Firms: The Impact of Different Types of Private Equity Investors and Institutional Environments. Strategic Management Journal, 31(5), 491-509

BVC website, 2010. Bolsa de Valores de Cabo Verde. http://www.bvc.cv/ Accessed 20 March 2010

BVRM website, 2009. Bourse régionale des valeurs Mobilières (BRVM) - UEMOA. http://www.brvm.org/ Accessed 20 March 2010

Certo, T. S., Covin, J. G., Daily, C. M., Dalton, D. R., 2001. Wealth and the effects of founder management among IPO-stage new ventures. Strategic Management Journal, Special Issue 22(6-7), 641-658

Chahine, S., Goergen, M., 2009. Underpricing and CEO stock options: Do board characteristics matter? Unpublished working paper, Cardiff Business School Working Paper A2009/6

Cohen, L., Frazzini, A., \& Malloy, C., 2008. The small world of investing: Board connections and Mutual Fund returns. Journal of Political Economy, 116(5), 951-971 
Daily, C.M., Certo, T., Dalton, D.R., Roengpitya, R., 2003. IPO underpricing: A metaanalysis and research synthesis. Entrepreneurship Theory Practice, 27, 271-295

Dalton, D.R., Daily, C.M., Ellstrand, A.E., Johnson, J.L., 1998. Meta-analytic review of board composition, leadership structure, and financial performance. Strategic Management Journal, 19, 269-290

Downes, D.H., Heinkel, R., 1982. Signalling and valuation of unseasoned new issues. Journal of Finance, 37(1), 1-10

DSX website, 2010. Bourse de Doula. http://www.douala-stock-exchange.com/index_us.php Accessed 20 March 2010

Englebert, P., 2000. Pre-Colonial institutions, Post-Colonial States, and Economic Development in Tropical Africa. Political Research Quarterly, 53 (1), 7-36

Fama, E.F., \& Jensen, M.C., 1983. Separation of ownership and control. Journal of Law and Economics, 26, 301-325

Filatotchev, I., Bishop, K., 2002. Board Composition, Share Ownership, and "Underpricing" of UK IPO Firms. Strategic Management Journal, 23, 941-955

Golden, B.R., Zajac, E.J., 2001. When will boards influence strategy? Inclination x Power = Strategic Change. Strategic Management Journal, 22, 1087-1111

Hearn, B., Piesse, J., 2009. Barriers to the development of small stock markets: A case study of Swaziland and Mozambique. Journal of International Development, forthcoming

Hearn, B., Piesse, J., 2010. Modelling size and illiquidity in West African equity markets. Applied Financial Economics, 13, 1011-1030

Hermalin, B., Weisbach, M., 2003. Boards of directors as an Endogenously determined institution: a survey of the economics literature. Economic Policy Review, 9, 7-26 
Higgins, M. C., \& Gulati, R., 1999. Getting off to a start: The effects of upper echelon affiliations on prestige of investment bank and IPO success. Unpublished working paper, Harvard Business School

Hjort, J., 2010. Pre-colonial culture, post-colonial economic success? The Tswana and the African miracle. The Economic History Review, 63(3), 688-709

Jensen, M. C., Meckling, W., 1976. Theory of the firm: managerial behavior, agency costs, and ownership structure. Journal of Financial Economics, 3, 305-360

Joireman, S. F., 2001. Inherited legal systems and effective rule of law: Africa and the colonial legacy. Journal of Modern African Studies, 39(4), 571-596

Joireman, S.F., 2005. The Evolution of the Common Law: Legal Development in Kenya and India. Commonwealth and Comparative Politics, 21, 190-210

Kalbers, L.P., Fogarty, T.J., 1998. Organizational and Economic Explanations of Audit Committee Oversight. Journal of Managerial Issues, 10(2), 129-151

La Porta, R., Lopez-de-Silanes, F., Schliefer, A., Vishny, R., 2002. Investor Protection and Corporate Valuation. The Journal of Finance, 27(3), 1147-1170

La Porta, R., Lopez-de-Silanes, F., Shleifer, A., 2008. The Economic Consequences of Legal Origins. Journal of Economic Literature, 46, 285-332

Lavelle K.C., 2001. Architecture of Equity Markets: The Abidjan Regional Bourse. International Organisation, 55(3), 717-42

Levine, R., 2005. Law, Endowments and Property Rights. Journal of Economic Perspectives, $19(3), 61-88$

North, D C (1991). Institutions. Journal of Economic Perspectives, American Economic Association, 5(1) 97-112

O'Hara, M., 2003. Presidential address: liquidity and price discovery. Journal of Finance, 58, $1335-1354$ 
Platteau, J-P., 2007. Constraints on African Economic Growth: The Institutional Legacy. Paper presented for the first IERC conference: the Economic Performance of Civilizations: Roles of Culture, Religion, and the Law, University of Southern California, Los Angeles, February 23-24, 2007

Quintyn M and Taylor M (2007). Building Supervisory Structures in Sub-Saharan Africa-An Analytical Framework. IMF Working Papers 07/18, International Monetary Fund Rossouw, G. J., 2005. Business, ethics and corporate governance in Africa. Business \& Society, 44(1), 94-106

Sanders, G.W., Boivie, S., 2004. Sorting things out: Valuing the controlling position of owners-managers in French IPO firms. Journal of Corporate Finance, 12, 270-295

Turley, S., Zaman, M., 2004. The corporate governance effects of audit committees. Journal of Management and Governance, 8(3), 305-332

Shivdasani, A., Yermack, D., 1999. CEO involvement in the selection of New Board members: An empirical analysis. Journal of Finance, 54, 1829-1853

Smith, G., Jefferis, K., 2005. The Changing Efficiency of African Stock Markets. South African Journal of Economics, 73(1), 54-67

West, A., 2006. Theorising South Africa's Corproate Governance. Journla fo Business Ethics, $68,433-448$

Williamson, O.E., 2000. The new institutional economics: Taking stock, looking ahead. Journal of Economic Literature, XXXVIII, 595-613 
Table 1. IPO sample characteristics by country

\begin{tabular}{|c|c|c|c|c|c|}
\hline Country & $\mathbf{N}$ & Sector & Head Office Location & Primary Listing Market & Purpose of listing \\
\hline \multirow[t]{4}{*}{ BRVM } & 1 & Telecommunications & Burkina Faso & BRVM-Cote d'Ivoire & Local fund raising \\
\hline & 1 & Finance & Niger & BRVM-Cote d'Ivoire & UMEAO financial integration \\
\hline & 1 & Finance & Benin & BRVM-Cote d'Ivoire & UMEAO financial integration \\
\hline & 1 & Distribution & Cote d'Ivoire & BRVM-Cote d'Ivoire & Local fund raising \\
\hline Cameroon & 1 & Agro-commodities & $\begin{array}{l}\text { French multinational } \\
\text { (Other locations include } \\
\text { Cambodia and France) } \\
\end{array}$ & Bourse de Douala & $\begin{array}{l}\text { Indigenisation/ Sale of Cameroonian privatization } \\
\text { agency (La Societe Nationale d'investissement du } \\
\text { Cameroun) }\end{array}$ \\
\hline Cape Verde & 2 & Finance & Cidade da Praia & Bolsa de Valores de Cabo Verde & Local fund raising \\
\hline \multirow[t]{2}{*}{ Islands } & 1 & Agro-commodities & Mindelo, São Vicente & Bolsa de Valores de Cabo Verde & Privatization \\
\hline & 1 & Oil Refinery & Mindelo, São Vicente & Bolsa de Valores de Cabo Verde & Privatization \\
\hline \multirow[t]{10}{*}{ Ghana } & 2 & Finance & Accra & Accra-Ghana Stock Exchange & Privatization \\
\hline & 1 & Finance & Accra & Accra-Ghana Stock Exchange & Local fund raising \\
\hline & 1 & Finance & Banjul, The Gambia & Accra-Ghana Stock Exchange & $\begin{array}{l}\text { Political: Anglophone West African financial } \\
\text { integration* }\end{array}$ \\
\hline & 1 & Consumer Staples & Accra & Accra-Ghana Stock Exchange & Local fund raising \\
\hline & 1 & Consumer Staples & Accra & Accra-Ghana Stock Exchange & Privatization \\
\hline & 1 & Consumer Products and Services & Accra & Accra-Ghana Stock Exchange & Local fund raising \\
\hline & 2 & High Technology & Accra & Accra-Ghana Stock Exchange & Local fund raising \\
\hline & 2 & Industrials & Accra & Accra-Ghana Stock Exchange & Local fund raising \\
\hline & 1 & Industrials & Accra & Accra-Ghana Stock Exchange & Privatization \\
\hline & 1 & Industrials & Accra & Accra-Ghana Stock Exchange & Privatization and Merger \\
\hline \multirow[t]{7}{*}{ Nigeria } & 4 & Finance & Lagos & Lagos-Nigeria Stock Exchange & Local fund raising \\
\hline & 3 & Finance & Lagos & Lagos-Nigeria Stock Exchange & Indigenisation/ Spin-off \\
\hline & 2 & Finance & Lagos & Lagos-Nigeria Stock Exchange & Local fund raising \\
\hline & 4 & Consumer Staples & Lagos & Lagos-Nigeria Stock Exchange & Spin-Off from conglomerate \\
\hline & 1 & Hotels and Accommodation & Lagos & Lagos-Nigeria Stock Exchange & Privatization \\
\hline & 1 & Industrials & Lagos & Lagos-Nigeria Stock Exchange & Spin-Off from conglomerate \\
\hline & 1 & Media and Entertainment & Abuja & Lagos-Nigeria Stock Exchange & Local fund raising \\
\hline \multirow[t]{2}{*}{ Botswana } & 3 & Finance & Gabarone & Botswana Stock Exchange & Local fund raising \\
\hline & 1 & Funeral Services & Gabarone & Botswana Stock Exchange & Local fund raising \\
\hline \multirow[t]{4}{*}{ Kenya } & 3 & Finance & Nairobi & Nairobi Stock Exchange & Local fund raising \\
\hline & 2 & Technology & Nairobi & Nairobi Stock Exchange & Local fund raising \\
\hline & 1 & Consumer Staples & $\begin{array}{l}\text { Local affiliate of US } \\
\text { conglomerate }\end{array}$ & Nairobi Stock Exchange & Indigenisation/ Spin-off \\
\hline & 1 & Utilities & Nairobi & Nairobi Stock Exchange & Local fund raising \\
\hline \multirow[t]{2}{*}{ Malawi } & 2 & Finance (and Property Investment) & Blantyre & Malawi Stock Exchange & Local fund raising \\
\hline & 1 & Technology & Blantyre & Malawi Stock Exchange & Local fund raising \\
\hline
\end{tabular}




\begin{tabular}{|c|c|c|c|c|c|}
\hline Mauritius & 1 & Finance & Port Louis & Mauritius Stock Exchange & Local fund raising \\
\hline Mozambique & 1 & Consumer Staples (Brewery) & Maputo & Bolsa de Valores de Maputo & $\begin{array}{l}\text { Indigenisation as part of conditions of joint-venture } \\
\text { of former state brewing enterprise with South } \\
\text { African Breweries (SAB Miller) }\end{array}$ \\
\hline Namibia & 1 & Finance (and Property Investment) & Windhoek & $\begin{array}{l}\text { Joint Primary Listing: Namibia } \\
\text { and Johannesburg Stock } \\
\text { Exchange (Africa Board) }\end{array}$ & Local fund raising \\
\hline \multirow{3}{*}{$\begin{array}{l}\text { Tanzania } \\
\text { Uganda }\end{array}$} & 2 & Finance & Dar Es Salaam & Dar Stock Exchange & Local fund raising \\
\hline & 1 & Finance & Kampala & Uganda Securities Exchange & Local fund raising \\
\hline & 1 & Media and Printing & Kampala & Uganda Securities Exchange & $\begin{array}{l}\text { Privatization and part-realization of private equity } \\
\text { stake }\end{array}$ \\
\hline \multirow[t]{4}{*}{ Zambia } & 1 & Finance & Lusaka & Lusaka Stock Exchange & Privatization \\
\hline & 1 & Technology & Lusaka & Lusaka Stock Exchange & $\begin{array}{l}\text { Indigenisation as part of merger between Celtel and } \\
\text { Kuwait's Zain telecommunications company }\end{array}$ \\
\hline & 1 & Hotels and Accommodation & Lusaka & Lusaka Stock Exchange & Local fund raising \\
\hline & 1 & Mining and Mineral Resources & Lusaka & Lusaka Stock Exchange & Privatization \\
\hline
\end{tabular}

Source: Compiled by author from prospectuses obtained direct from national stock exchanges and Thomson Perfect Information

Notes: *indicates that the listing of Gambia's Trust Bank was facilitated by Ghana's Databank securities firm. This has involved the establishment of a small office in

Banjul, Gambia through which order flow from the Gambia is precipitated. The listing was motivated politically as part of Anglophone English common law West Africa and

through Trust Bank's expansion into other Anglophone regional markets. 
Table 2. Distribution of IPOs, initial returns and cost of equity by country

This table presents the distribution of IPOs and initial returns statistics by listing country. Initial return is the secondary market closing price at end of second week of listing divided by the final offer price, minus 1. Costs of equity are either sourced direct from firm or where these are unavailable from estimation using Gordon and Shapiro (1956) dividend discount method where the expected dividend growth rate is calculated using balance sheet data from IPO listing prospectus

\begin{tabular}{|c|c|c|c|c|c|c|c|c|}
\hline \multirow[t]{2}{*}{ Legal Origin } & \multirow[t]{2}{*}{ Country } & \multirow[b]{2}{*}{$\mathbf{N}$} & \multicolumn{3}{|c|}{ Offering Size (US\$m) } & \multicolumn{3}{|c|}{ Initial Returns } \\
\hline & & & Mean & Median & Std. dev. & Mean & Median & Std. dev. \\
\hline \multirow[t]{3}{*}{ French civil code } & BRVM/ Cote d'Ivoire & 4 & 16.90 & 1.79 & 30.99 & 0.141 & 0.106 & 0.098 \\
\hline & Mauritius & 1 & 7.24 & 7.24 & -- -- & 0.000 & 0.000 & 0.000 \\
\hline & Cameroon & 1 & 6.46 & 6.46 & -- -- & 0.000 & 0.000 & 0.000 \\
\hline \multirow[t]{2}{*}{ Portuguese civil code } & Cape Verde Islands & 4 & 9.50 & 8.87 & 6.64 & 0.011 & 0.008 & 0.013 \\
\hline & Mozambique & 1 & 2.45 & 2.45 & -- -- & 0.000 & 0.000 & 0.000 \\
\hline Civil code & & 11 & 11.07 & 4.250 & 18.08 & 0.055 & 0.017 & 0.087 \\
\hline \multirow[t]{9}{*}{ English common law } & Botswana & 4 & 6.40 & 6.50 & 1.53 & 0.311 & 0.186 & 0.310 \\
\hline & Ghana & 13 & 12.47 & 3.03 & 16.63 & 0.086 & 0.100 & 0.201 \\
\hline & Kenya & 7 & 134.38 & 32.95 & 241.06 & 0.769 & 0.470 & 0.825 \\
\hline & Nigeria & 15 & 180.70 & 124.51 & 210.89 & 0.215 & 0.079 & 0.327 \\
\hline & Malawi & 3 & 8.69 & 6.30 & 8.85 & 0.519 & 0.000 & 0.898 \\
\hline & Namibia & 1 & 10.98 & 10.98 & -- -- & 0.109 & 0.000 & 0.000 \\
\hline & Uganda & 2 & 5.88 & 5.88 & 6.65 & 0.276 & 0.276 & 0.071 \\
\hline & Tanzania & 2 & 24.88 & 24.88 & 33.55 & 0.536 & 0.536 & 0.373 \\
\hline & Zambia & 4 & 44.10 & 18.18 & 62.94 & 0.246 & 0.140 & 0.327 \\
\hline Common Law & & 51 & 80.66 & 18.67 & 160.24 & 0.391 & 0.222 & 0.619 \\
\hline
\end{tabular}

Notes: (1) $\mathbf{N}$ relates to sample size 
Table 3. Spearman's Rank correlations for IPO firm variables

\begin{tabular}{|c|c|c|c|c|c|c|c|c|c|c|c|c|c|c|c|}
\hline Variable & Mean & SD & 1 & 2 & 3 & 4 & 5 & 6 & 7 & 8 & 9 & 10 & 11 & 12 & 13 \\
\hline Underpricing (2 weeks) & 38.92 & 62.62 & 1.00 & & & & & & & & & & & & \\
\hline Underpricing (4 weeks) & 47.81 & 67.80 & 0.96 & 1.00 & & & & & & & & & & & \\
\hline No OECD Directors & 0.83 & 1.37 & 0.19 & 0.13 & 1.00 & & & & & & & & & & \\
\hline No. Foreign Directors & 1.45 & 1.95 & 0.03 & -0.02 & $0.72 \dagger \dagger$ & 1.00 & & & & & & & & & \\
\hline No. High Society Directors & 2.68 & 2.01 & $0.24 * *$ & 0.19 & -0.08 & -0.19 & 1.00 & & & & & & & & \\
\hline Board Size & 8.51 & 2.91 & 0.17 & 0.13 & 0.01 & 0.07 & $0.65 \div \dagger$ & 1.00 & & & & & & & \\
\hline Board Independence Ratio & 66.06 & 24.28 & 0.05 & 0.02 & 0.09 & 0.09 & $0.26 * *$ & 0.19* & 1.00 & & & & & & \\
\hline Committee & 0.74 & 0.44 & $0.28 * *$ & $0.27 * *$ & $0.25 * *$ & 0.06 & 0.01 & -0.01 & -0.06 & 1.00 & & & & & \\
\hline Legal Origin & 0.04 & 0.20 & $-0.27 * *$ & $-0.27 * *$ & -0.16 & $0.20 * *$ & -0.13 & -0.02 & -0.02 & 0.12 & 1.00 & & & & \\
\hline Log (Revenues) & 7.26 & 0.87 & 0.13 & 0.12 & $0.23 * *$ & 0.18 & $0.19 *$ & $0.31 * *$ & 0.06 & 0.17 & -0.02 & 1.00 & & & \\
\hline $\log ($ Age $)$ & 1.24 & 0.40 & 0.00 & -0.02 & 0.00 & 0.02 & -0.07 & -0.02 & -0.06 & $0.20 *$ & 0.14 & -0.02 & 1.00 & & \\
\hline Basic Materials/ Construction & 0.04 & 0.20 & $0.30 * *$ & $0.30 * *$ & 0.06 & -0.03 & $0.27 * *$ & 0.14 & $0.21 *$ & 0.12 & -0.04 & -0.05 & $0.33 * *$ & 1.00 & \\
\hline Log(Shares Offered/ Total & & & & & & & & & & & & & & & \\
\hline Outstanding Shares post-IPO) & -0.54 & 0.23 & 0.21 & $0.27 * *$ & -0.10 & 0.00 & -0.18 & 0.00 & -0.06 & -0.04 & -0.09 & -0.07 & 0.07 & -0.17 & 1.00 \\
\hline
\end{tabular}

Notes: (1) The data have been sourced manually from the last prospectus lodged with the relevant securities exchange or national regulator immediately prior to listing.

All financial variables are expressed either as ratios or in thousands of US dollars. Firm age is measured in years between inception and IPO date.

(2) * Significant at $10 \%$ confidence level; ** Significant at $5 \%$ confidence level; $\uparrow$ Significant at $1 \%$ confidence level; $\uparrow \dagger$ Significant at $0.5 \%$ confidence level 
Table 4. The impact of board characteristics on underpricing

Regression models are unbalanced panel OLS regressions relating control variables and board characteristics to underpricing at 2 and 4 weeks. Board characteristics are board size, defined as number of executive and non-executive directors, board independence ratio, defined as proportion of independent directors to executive directors and committee, defined as a dummy variable taking value 1 if independent board level audit, accounting and oversight committees have been established and 0 otherwise. Industry effects take value of 1 of IPO firm is in Basic Materials and Construction and 0 otherwise. Firm control variables are natural logarithm of firm revenues in year pre-IPO (in US\$) and natural logarithm of firm age, itself the difference between foundation and listing date. IPO characteristics are defined as natural logarithm of shares offered at IPO to total outstanding shares (issued and fully paid up obtained from IPO prospectuses). Legal controls are the legal origin dummy taking value 1 if civil code law and 0 for English common law.

\begin{tabular}{|c|c|c|c|c|c|c|}
\hline \multirow[t]{3}{*}{ Board determinants } & \multicolumn{2}{|c|}{ Board Size } & \multicolumn{2}{|c|}{ Board Independence Ratio } & \multicolumn{2}{|c|}{ Committee } \\
\hline & $\begin{array}{l}\text { Underpricing } \\
\text { ( } 2 \text { weeks) }\end{array}$ & $\begin{array}{l}\text { Underpricing } \\
\text { (4 weeks) }\end{array}$ & $\begin{array}{l}\text { Underpricing } \\
\text { ( } 2 \text { weeks) }\end{array}$ & $\begin{array}{l}\text { Underpricing } \\
\text { (4 weeks) }\end{array}$ & $\begin{array}{l}\text { Underpricing } \\
\text { ( } 2 \text { weeks) }\end{array}$ & $\begin{array}{l}\text { Underpricing } \\
(4 \text { weeks) }\end{array}$ \\
\hline & Model 1 & Model 2 & Model 3 & Model 4 & Model 5 & Model 6 \\
\hline Intercept & $23.610(44.99)$ & $33.291(45.80)$ & $36.476(63.54)$ & $43.332(54.88)$ & $36.535(58.95)$ & $41.465(51.85)$ \\
\hline \multicolumn{7}{|l|}{ Corporate Governance } \\
\hline Board Size & $2.601(3.40)^{*}$ & $2.041(3.21)^{*}$ & & & & \\
\hline Board Independence Ratio & & & $0.105(0.18)$ & $0.084(0.20)$ & & \\
\hline Committee & & & & & $32.205(14.48) * * *$ & $37.438(16.94) * * *$ \\
\hline \multicolumn{7}{|l|}{ Industry Specific } \\
\hline Basic Materials and Construction & $131.728(54.35) \dagger$ & $163.361(28.14) \dagger \dagger$ & $133.036(57.36) \dagger$ & $164.357(31.35) \dagger \dagger$ & $127.869(53.13) \dagger$ & $157.277(27.42) \dagger \dagger$ \\
\hline \multicolumn{7}{|l|}{ Legal Origins } \\
\hline Legal Origin & $-25.658(10.90) \dagger$ & $-31.369(10.81) \dagger \dagger$ & $-24.080(10.38) \dagger$ & $-30.125(10.31) \dagger \dagger$ & $-33.168(10.53) \dagger \dagger$ & $-40.524(10.32) \dagger \dagger$ \\
\hline \multicolumn{7}{|l|}{ Firm Characteristics } \\
\hline Log (Revenues) & $4.068(5.83)^{*}$ & $5.667(6.40)^{*}$ & $4.436(5.70)^{*}$ & $5.952(6.49)^{*}$ & $3.211(4.98)$ & $4.364(4.98)$ \\
\hline $\log ($ Age $)$ & $-9.113(25.04)$ & $-12.299(28.99)$ & $-9.136(26.26)$ & $-12.306(29.93)$ & $-14.125(27.71)$ & $-17.683(30.87)$ \\
\hline \multicolumn{7}{|l|}{ IPO Characteristics } \\
\hline $\begin{array}{l}\text { Log(Shares Offered/ Total } \\
\text { Outstanding Shares post-IPO) }\end{array}$ & $54.076(15.64) \dagger \dagger$ & $62.747(18.37) \dagger \dagger$ & $54.861(16.72) \dagger \dagger$ & $63.36(18.96) \dagger \dagger$ & $57.338(18.02) \dagger \dagger$ & $66.138(20.42) \dagger \dagger$ \\
\hline Country Fixed Effects & No & No & No & No & No & No \\
\hline F-test & $2.84(0.02)$ & $3.69(0.00)$ & $2.63(0.03)$ & $3.57(0.01)$ & $3.30(0.01)$ & $4.50(0.00)$ \\
\hline Observations & 56 & 56 & 56 & 56 & 56 & 56 \\
\hline Adjusted $\mathrm{R}^{2}$ & 0.1671 & 0.2271 & 0.1513 & 0.2189 & 0.2008 & 0.2765 \\
\hline
\end{tabular}

Notes: (1) $* \mathrm{p}<0.25 ; * * \mathrm{p}<0.10 ; * * * \mathrm{p}<0.05 ; \dagger \mathrm{p}<0.01 ; \dagger \uparrow \mathrm{p}<0.005$. Standard errors are in parentheses (2) White cross-section standard errors \& covariance (d.f. corrected). 
Table 5. The impact of director characteristics on underpricing

Regression models are unbalanced panel OLS regressions relating control variables and board characteristics to underpricing at 2 and 4 weeks. Director characteristics are defined as the number of OECD, Foreign and local indigenous high society directors respectively. Industry effects take value of 1 of IPO firm is in Basic Materials and Construction and 0 otherwise. Firm control variables are natural logarithm of firm revenues in year pre-IPO (in US\$) and natural logarithm of firm age, itself the difference between foundation and listing date. IPO characteristics are defined as natural logarithm of shares offered at IPO to total outstanding shares (issued and fully paid up obtained from IPO prospectuses). Legal controls are the legal origin dummy taking value 1 if civil code law and 0 for English common law.

\begin{tabular}{|c|c|c|c|c|c|c|}
\hline \multirow[t]{3}{*}{ Directors: } & \multicolumn{2}{|c|}{ No. OECD Directors } & \multicolumn{2}{|c|}{ No. Foreign Directors } & \multicolumn{2}{|c|}{ No. Local High Society Directors } \\
\hline & $\begin{array}{l}\text { Underpricing } \\
\text { (2 weeks) }\end{array}$ & $\begin{array}{l}\text { Underpricing } \\
\text { (4 weeks) }\end{array}$ & $\begin{array}{l}\text { Underpricing } \\
\text { (2 weeks) }\end{array}$ & $\begin{array}{l}\text { Underpricing } \\
\text { (4 weeks) }\end{array}$ & $\begin{array}{l}\text { Underpricing } \\
\text { (2 weeks) }\end{array}$ & $\begin{array}{l}\text { Underpricing } \\
\text { (4 weeks) }\end{array}$ \\
\hline & Model 7 & Model 8 & Model 9 & Model 10 & Model 11 & Model 12 \\
\hline Intercept & $24.881(91.86)$ & $14.924(82.92)$ & $33.754(91.46)$ & $27.018(79.32)$ & $26.069(102.89)$ & $13.043(95.33)$ \\
\hline \multicolumn{7}{|l|}{ Director characteristics } \\
\hline No. OECD Directors & $-2.134(3.32)^{*}$ & $-3.470(3.92) *$ & & & & \\
\hline No. Foreign Directors & & & $-5.030(3.47)^{* * * *}$ & $-6.643(3.70)^{* * * *}$ & & \\
\hline No. Local High Society Directors & & & & & $4.949(6.37)^{*}$ & $1.515(5.81)$ \\
\hline \multicolumn{7}{|l|}{ Industry Specific } \\
\hline Basic Materials and Construction & $140.501(49.17) \dagger \dagger$ & $173.386(21.81) \dagger \dagger$ & $141.426(44.53) \dagger$ & $174.347(19.24) \dagger$ & $120.021(54.10)^{* * *}$ & $166.022(37.22) \dagger \dagger$ \\
\hline \multicolumn{7}{|l|}{ Legal Origins } \\
\hline Legal Origin & $-12.650(17.65)$ & $-16.373(18.00)$ & $-0.393(22.34)$ & $-1.417(23.02)$ & $-25.504(9.19) \dagger \dagger$ & $-35.84(7.89) \dagger \dagger$ \\
\hline \multicolumn{7}{|l|}{ Firm Characteristics } \\
\hline Log (Revenues) & $7.898(8.10)^{*}$ & $11.588(9.53)^{*}$ & $8.295(7.66)^{*}$ & $11.972(9.30)^{* *}$ & $5.405(11.77) *$ & $10.623(12.58) *$ \\
\hline $\log ($ Age $)$ & $-10.520(27.66)$ & $-12.763(29.70)$ & $-11.306(27.16)$ & $-13.751(28.99)$ & $-5.022(26.57)$ & $-8.497(30.52)$ \\
\hline \multicolumn{7}{|l|}{ IPO Characteristics } \\
\hline $\begin{array}{l}\text { Log(Shares Offered/ Total } \\
\text { Outstanding Shares post-IPO) }\end{array}$ & $60.846(19.07) \dagger \dagger$ & $70.219(20.51) \dagger$ & $71.455(28.00) \dagger \dagger$ & $84.170(29.81) \dagger \dagger$ & $68.896(19.52) \dagger \dagger$ & $76.139(22.19) \dagger \dagger$ \\
\hline Country Fixed Effects & No & No & No & No & No & No \\
\hline F-test & $2.32(0.05)$ & $3.31(0.01)$ & $2.58(0.03)$ & $3.74(0.00)$ & $2.17(0.07)$ & $2.69(0.03)$ \\
\hline Observations & 52 & 52 & 52 & 52 & 47 & 47 \\
\hline Adjusted $\mathrm{R}^{2}$ & 0.1343 & 0.2133 & 0.1569 & 0.2440 & 0.1320 & 0.1803 \\
\hline
\end{tabular}

Notes: (1) $* \mathrm{p}<0.25 ; * * \mathrm{p}<0.10 ; * * * \mathrm{p}<0.05 ; \dagger \mathrm{p}<0.01 ; \dagger \mathrm{p}<0.005$. Standard errors are in parentheses (2) White cross-section standard errors \& covariance (d.f. corrected). 